\title{
Assessing the Leadership Skills of the Chiefs of Police in the Towns of Nueva Ecija, Philippines: A Dichotomy between Managerial Competence and Decision Making Ability
}

\author{
Jesster P. Eduardo, Arneil G. Gabriel \\ Nueva Ecija University of Science and Technology, General Tinio, Cabanatuan City, Philippines \\ Email:pulayok@yahoo.com,opats14@yahoo.com
}

How to cite this paper: Eduardo, J. P., \& Gabriel, A. G. (2017). Assessing the Leadership Skills of the Chiefs of Police in the Towns of Nueva Ecija, Philippines: A Dichotomy between Managerial Competence and Decision Making Ability. Open Journal of Leadership, 6, 142-159.

https://doi.org/10.4236/oj1.2017.64011

Received: October 8, 2017

Accepted: December 10, 2017

Published: December 13, 2017

Copyright $\odot 2017$ by authors and Scientific Research Publishing Inc. This work is licensed under the Creative Commons Attribution International License (CC BY 4.0).

http://creativecommons.org/licenses/by/4.0/

(c) (i) Open Access

\begin{abstract}
The study of organizational behavior and performance is often linked to organizational leadership. The Police force as civilian in character is mandated to maintain peace and order in the community and is expected to effectively and efficiently control crime. Short to meet the mandate calls for a study of police leadership. The performance of police office as a group depends to a great extent on the leadership skills of its Chief of Police (COP). The study used the Attribution Theory to analyze the leadership skills of police offices in Nueva Ecija, Philippines. Better police performance is first and foremost an attribute of a skilled police chief. By using a mixture of quantitative and qualitative methods of research, the study measured the leadership domains of "managerial competence and decision-making ability" of the participating heads of police offices. The paper argued that leadership is vital to a performing police office and thus "managerial competence" and "decision-making ability" as important domains of leadership must always be part of the professional growth and development of the COP. The dichotomy between the two domains must remain at bay while training and education programs are instituted to the level of the two leadership domains thereby improving considerably the performance of the police offices.
\end{abstract}

\section{Keywords}

Leadership, Managerial Competence, Decision Making Ability, Chief of Police, Philippines

\section{Introduction}

The police leadership and performance of police station are interlinked. Consi- 
dering the nature of the research, there is a dearth of literature on this study. Hence, the researchers offer the following related writings and studies: In England, police leadership style was studied using qualitative approach characterized as context sensitive approach to come up with the new leadership style of police leaders (Bryman, Stephens, \& Campo, 1996). According to Fyfe, Greene, Walsh, Wilson, \& McLaren (1997), police leadership and administration focus on the police chief executive as a multi-dimensional leader creating performance for the police station. While police leadership affects citizens' attitudes towards the police, police misconduct downgrades the trust and confidence of the community to the police precinct (Weitzer, 2002). Police capacity is indeed a factor to lessen the opportunity and cases of crimes. The control of crime in the Hong Kong's mass transport system was identified as attributed to police response to control misbehaviors in the underground train tunnel (Gaylord \& Galliher, 1991) and the ability of police leadership to instill discipline among its ranks. In the Philippines, the legitimacy of the police force is rooted in the Philippine Constitution (1987) Article XVI, Section 6, which states that: "The State shall establish and maintain one police force, which shall be national in scope and civilian in character, to be administered and controlled by a National Police Commission." Effectively, Republic Act 8551 (1998) Section 2, highlights the civilian character of the police force and maintains the need to observe professionalism at all cost:

"The PNP shall be a community and service oriented agency responsible for the maintenance of peace and order and public safety; and the PNP shall be so organized to ensure accountability and uprightness in police exercise of discretion as well as to achieve efficiency and effectiveness of its members and units in the performance of their functions. COPs shall be professional managers; hence, they must be proficient so that they could effectively realize the goals of the PNP."

However, recent pieces of evidence proved that the Philippine National Police personnel are themselves involved in some illegal activities such as in illegal logging, (Van der Ploeg, Van Weerd, Masipiqueña, \& Persoon, 2011), illegal fishing, or the failure to enforce the law due to lack of resources and trained personnel (Fabinyi, 2007). Some have been involved in illegal drugs trade and cases of rob out. The situation remains after several institutional and national policies are implemented to toe the line of police personnel and bring back the trust and confidence of the community in the police force. This gap between the ideal condition and actual practice of police personnel inspired the researchers to make a study on the leadership capability of Chiefs of Police in managing their police offices. The study argues that the inability of some police personnel to maintain the performance of their mandated functions emanates from the incapability of their Chiefs of Police, as leaders to assert their power and authority. The leadership capability of COPs shall be measured in terms of Managerial Competence and Decision-Making Ability. The two domains of leadership are essential to maintain performance level of police offices. 
The study, therefore, posed the following problems, to wit:

1) What is the level of competence of COPs in terms of Managerial Competence and Decision-Making Ability (MCDMA) as perceived by COPs and their Police Personnel?

2) Is there a significant difference in the MCDMA of COPs based on the perception of COPs and their Police Personnel?

3) Is there a significant relationship between the Managerial Competence of the COPs and their Decision-Making Ability?

4) Is there a significant relation of Age and Length of Service of COPs to their MCDMA as perceived by COPs and their Police Personnel?

The following are the hypotheses, to wit:

1) There is no significant difference in the MCDMA of COPs based on the perception of COPs and their Police Personnel.

2) There is no significant relation between Managerial Competence of COPs and their Decision-Making Ability.

3) There is no significant relation of Age and Length of Service of the COPs to their MCDMA as perceived by COPs and their Police Personnel.

\section{Methodology}

\subsection{Conceptual Framework}

Leadership in the context of the study is measured by the manner Chiefs of Police maintain Managerial Competence and Decision-Making Ability leading to efficient and effective management of police stations. A research conducted in 1950s showed "police work is complex", that police use enormous discretion, that discretion is at the core of police functioning... (Kelling, 1999). There are three elements common to all successful managers in government and industry, which are: the will to power, the will to manage, and empathy (Rodriguez \& Echancis, 2001). Managers direct their subordinates in the completion of tasks toward the accomplishment of a specific organizational goal (Ortmeier \& Davis, 2012). To be a manager requires competence and performance of a high order (Drucker, 1974). The first managerial skill is, therefore, the making of decisions (Koontz \& O’Donnel, 1972; Drucker, 1974). According to Bohm \& Haley (2005), making the wrong decision can be fatal for the officer or other person. Gorry \& Scott Morton (1971) mentioned that decision making is the core of management and aims at selecting the best alternative to achieve an objective. It is the act of choosing from among the alternative courses of action (Timpac, 2012) on the basis of relevant information (Pitz \& McKillip, 1984) which may also include inaction (Ireland \& Miller, 2004). It involves the application of knowledge, experience, and mental and moral skills and powers to determine what actions should be taken to deal with a variety of problem situations (Swanson, Territo, \& Taylor, (2008). Fayol recognized that managers needed to have knowledge on how to "manage" the organization, rather than to perform labor (Fayol, 1947; 
Worall, Gaines, Southerland, \& Angell, 2003). In the study of Guibong (1994), police officers were found to be equipped with an inquisitive mind, good reasoning ability, observant, imaginative and the ability to interrelate facts. All these attributes are concepts related to police leadership which in this study pertains to managerial competence and decision-making ability.

\subsection{Theoretical Framework}

The study adheres to the attribution theory of leadership. This theory argues that whatever happens to the organization may be attributed to things which could either prevent or enhance realization of mandated goals (Calder, 1977). The entire organizational behavior is affected by numerous factors present in the external and international environment of the police station. One major attribution to the function of policing among personnel is the leadership of the Chief of Police. The better the leadership capability of the Chief of Police, the better the organization performs its mandated duties. Attribution is the process by which individuals explain the causes of behavior and events. Weiner's attribution theory is about achievement. According to him, the most important factors affecting attributions are ability, effort, task difficulty, and luck. These are the factors affecting achievement of goals. In this context, the study sees the failure of the police to achieve organizational goals and functions and this is attributed not to the personnel but to the person leading the police station-the Chief of Police. With this theoretical back drop, the following research paradigm is drawn, to wit.

The Figure 1 shows the relationship between variables. By using the systems model, the study considered managerial competence and decision making ability as measures of leadership of a police chief. These are inputs of the study that were processed to determine more or less the police office performance. It is processed by measuring the other subdomains of competence and decision making ability. How the study would process the same would lead to the output which later on shall serve as another input to analyze leadership skills and office performance. Part of the output of course is the recommendation necessary to improve the office performance. These could be in the form of training, seminar or even a formal education.

\subsection{The Research Locale}

The study locale is in the Province of Nueva Ecija, Philippines. The archipelago consists of 7107 islands but geographically, from North to South, it has three main islands: Luzon, Visayas and Mindanao. Each of the main islands is divided into administrative regions and provinces (Gabriel, 2017). Nueva Ecija is a typical province in the archipelago having agriculture as the backbone of the economy. As of 2010, the province has a total population of $1,955,373$ persons greater than $1,659,883$ by 295,490 as of July 10,2013 . The map of the province is shown below (Figure 2). 


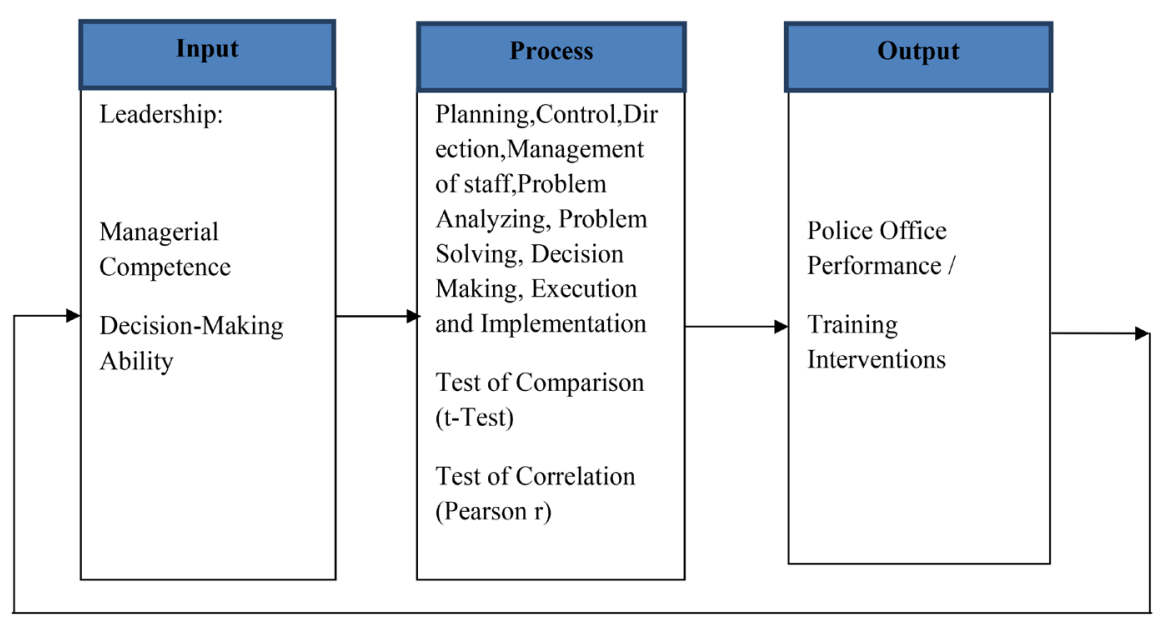

Feedback

Figure 1. Research paradigm.

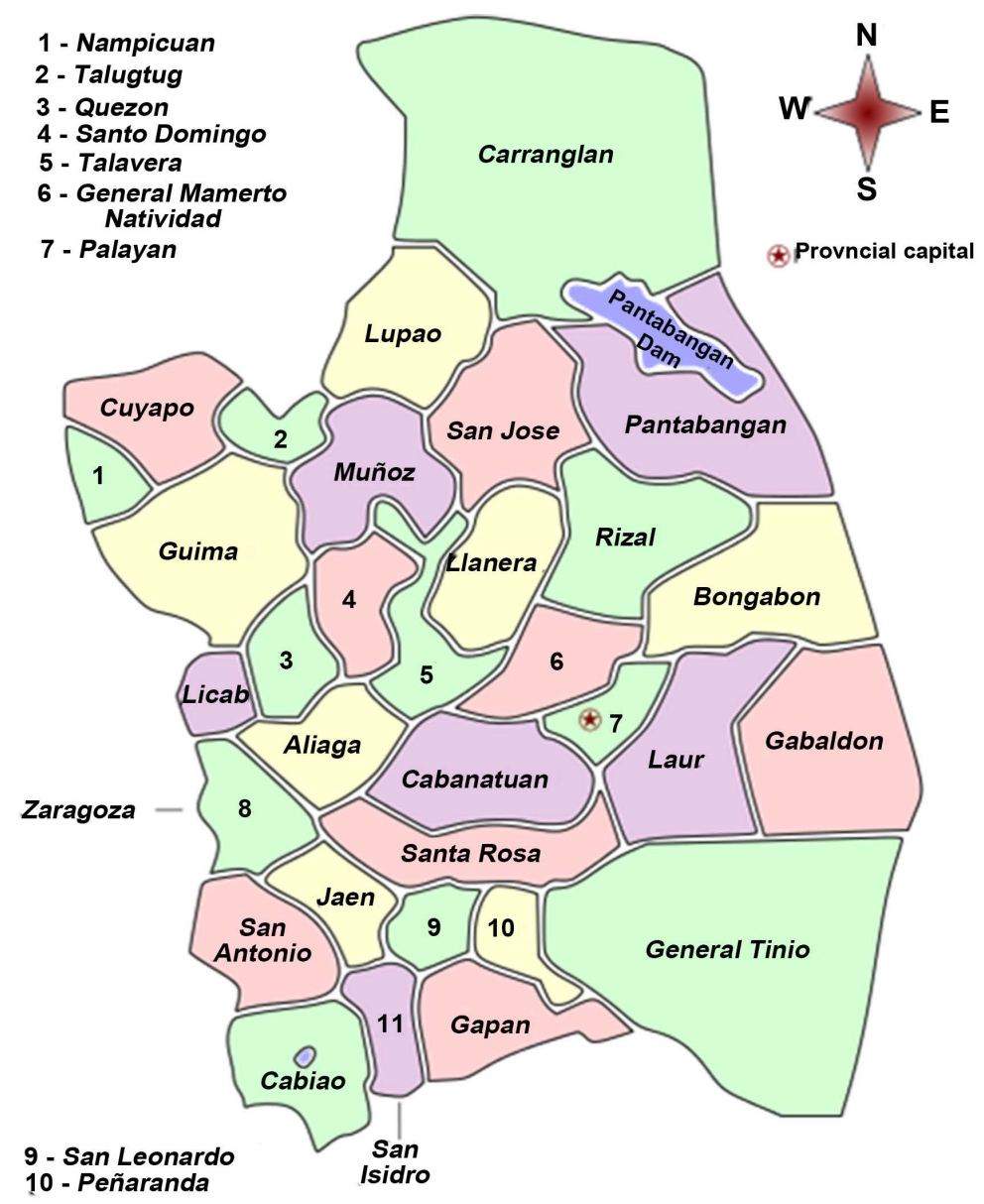

Figure 2. The map of the Province of Nueva Ecija, Philippines. Source: Google Map.

\subsection{Research Design}

The study used the Descriptive Survey Method. This method involves the collection of data in order to test hypotheses or answer questions. According to Ku- 
mar (2014), this method can systematically describe a situation, problem, phenomenon, service or programs, or provides information or describes the attitude towards an issue.

\subsection{Data Gathering Procedure}

There were 31 COPs and 310 Police Personnel as respondents. The COPs and their Police Personnel answered the same set of questionnaire-checklist (Appendix) as the main instrument that was correlated to the perception of their respective COPs. The instrument consisted of two groups namely: Managerial Competence with three areas and Decision-Making Ability with four areas. Interview with both groups of respondents was conducted and its results were considered in the processing of data. The researchers used the Simple Random Sampling method to extract the number of Police Personnel. The respondents were offered four options from which to select responses and descriptors (see Table 1 and Table 2).

\subsection{Reliability of the Instrument}

The questionnaire-checklist was tested using twenty (20) Police Personnel and ten (10) Chiefs of Police from the nearby province (Tarlac) and it was found reliable using Cronbach's Alpha.

\subsection{Statistical Tools}

To verify the hypotheses, hypothesis number 1 was tested using the t-Test while Hypotheses 2 and 3 were verified through Pearson Product-Moment Correlation.

\section{Results and Discussions}

\subsection{The Level of Competence of Chief of Police (COPs) on Managerial Competence and Decision-Making Ability}

In terms of Managerial Competence, the Table 3 shows that both groups of respondents considered COPs as Very Much Competent. Hence, COPs carried out to a full extent the managerial competence areas. Police Personnel agreed that their COPs are very much capable in managerial aspect; however, both COPs and Police Personnel perceived that COPs still have to improve in terms of Management of Staff with an area mean of 3.59 and 3.36, respectively. Staff are

Table 1. Response Mode on the MCDMA of COPs.

\begin{tabular}{ccc}
\hline Index & Semantic differential & Verbal description \\
\hline 4 & - Always & - Carried out to a full extent. \\
3 & - Very often & - Carried out to a good extent. \\
2 & - Often & - Carried out to a fairly good extent. \\
1 & - Rarely & - Carried out to a very poor extent. \\
\hline
\end{tabular}


Table 2. Descriptors of MCDMA of COPs.

\begin{tabular}{cl}
\hline Limit of index & \multicolumn{1}{c}{ Semantic differential } \\
\hline $3.26-4.0$ & - Very Much Competent (VMC) \\
$2.51-3.25$ & - Very Competent (VC) \\
$1.76-2.50$ & - Competent (C) \\
$1.00-1.75$ & - -Slightly Competent (SC) \\
\hline
\end{tabular}

Table 3. Level of Competence of COPs on MCDMA.

\begin{tabular}{ccccc}
\hline \multirow{2}{*}{ Areas/Items } & \multicolumn{3}{c}{ COPs } & \multicolumn{2}{c}{ Police personnel } \\
\cline { 2 - 4 } & WM & Description & WM & Description \\
\hline I) Managerial competence in management of planning procedures & \\
\hline Area mean & 3.63 & VMC & 3.39 & VMC \\
\hline II) Managerial competence in organization, control, and direction of structures & \\
\hline Area mean & 3.69 & VMC & 3.39 & VMC \\
\hline III) Managerial competence in management of staff & & \\
\hline Area mean & 3.59 & VMC & 3.36 & VMC \\
\hline IV) Decision-making ability in defining the problem & & \\
\hline Area mean & 3.40 & VMC & 3.33 & VMC \\
\hline V) Decision-making ability in analyzing the problem & & \\
\hline Area mean & 2.98 & VC & 3.04 & VC \\
\hline VI) Decision-making ability in making the decisions & & \\
\hline Area mean & 3.04 & VC & 2.90 & VC \\
\hline Area mean & 3.41 & VMC & 2.26 & C \\
\hline Overall mean & VMC & 3.17 & VC \\
\hline DII) Decision-making ability in executions and implementations of decisions & \\
\hline
\end{tabular}

responsible for internal operations of police stations; they should be managed rationally and properly in order to ensure competence in the workplace. Area III shows the COPs and Police Personnel perception on the COPs capability along the line of management of staff. Of all the items, it is item 6 that has the lowest mean which is 3.22 and 3.31, respectively. This implies that COPs shall maintain professionalism and competence in settling issues affecting their personnel in their level. Also, Police Personnel perceived that their COPs have the lowest mean on item 10 which is 3.31 . Interviews revealed that politics or "palakasan system" in the organization exists. Consquently, a police personnel could be promoted if he knows someone, either a politician or a "higher up" in the organization.

Under Decision-Making Ability, COPs and Police Personnel vary in their perception particularly in terms of Executions and Implementations of Decisions with an area mean of 3.53 (VMC) and 3.17 (MC), respectively. However, both similarly perceived that COPs are VMC on Defining the Problem, and VC 
on Analyzing the Problem, and in Making the Decisions. Data show that COPs perceived themselves the lowest in Analyzing the Problem with an area mean of 2.98 (VC) while the Police Personnel perceived their COPs the lowest in Making Decisions with an area mean of 2.90 (VC). COPs shall be masters in solving problem; they must possess abilities in analyzing a problem.

Area $\mathrm{V}$ shows that COPs have the lowest perception on item 7 with a mean of 1.81 (C) while Police Personnel perceived their COPs at the lowest on item 5 with a mean of 1.89 (C). It implies that COPs listen and accept worthy suggestions by their staff which indicates participative decision-making in analyzing problems.

In Making Decisions, area VI shows that COPs have the lowest perception on item 6 with a mean of $2.00(\mathrm{C})$ while the Police Personnel perceived their COPs are the lowest on items 5 and 8 with means of 2.06 (C) and 2.07 (C), respectively. It signifies that COPs seek the ideas of their personnel before making decisions but still have to improve their ability in decision-making. Thus, COPs shall make accurate, legal, and relevant decisions. Ireland \& Miller (2004) stated that making the wrong decision can be fatal for the officer or other person.

The overall mean for COPs is 3.41 (VMC) which means that COPs carried out to a full extent the Managerial and Decision-Making areas while the Police Personnel perception is 2.26 (C) which means that COPs carried out to an average extent only. This entails that COPs believed that they have exerted their best, but their Police Personnel perceived that they still need improvement.

\subsection{Significant Difference in the MCDMA of the COPS}

Table 4 presents that only Areas I and II have higher Computed Values than their respective Critical Values at 0.05 level of significance; the Ho is rejected. Hence, there is a significant difference in the MCDMA of the COPs only on the two identified areas. However, the Computed Values of Areas III, IV, V, VI, and VII are lower than their respective Critical Values at 0.05 level of significance; the Ho is accepted. It implies that COPs have the same perception as that of their Police Personnel on most of the areas of MCDMA.

\subsection{Relation between the Managerial Competence of COPs and Their Decision Making Ability}

Table 5 presents that Managerial Competence particularly in Areas II and III significantly correlates with Decision-Making Ability specifically only on Area V at 0.05 level of significance. The Ho is rejected. This implies that COPs who are capable in the Organization, Control \& Direction of Structures and Management Staff are also proficient in Analyzing a Problem. On the other hand, the rest of the areas within MCDMA are not significantly interrelated which implies that each area does not affect the other areas. It also signifies that "COPs who are competent in managerial aspect" does not mean that they are also capable in decision-making or vice versa. Similarly, interview showed that Police Personnel acknowledged that COPs must be competent in managerial and in 
Table 4. Significant difference in the MCDMA of the COPS.

\begin{tabular}{|c|c|c|c|c|c|}
\hline & MCDMA areas & Critical $t$ & Computed $t$ & Decision & Interpretation \\
\hline I) & $\begin{array}{l}\text { Managerial competency on } \\
\text { management of planning } \\
\text { procedures }\end{array}$ & 2.144786688 & $7.68932 \mathrm{E}-05$ & Reject Ho & Significant \\
\hline II) & $\begin{array}{l}\text { Managerial competency in } \\
\text { terms of organization, } \\
\text { control, and direction of } \\
\text { structures }\end{array}$ & 2.144786688 & $8.88921 \mathrm{E}-06$ & Reject Ho & Significant \\
\hline III) & $\begin{array}{l}\text { Managerial competency on } \\
\text { management of staff }\end{array}$ & 2.228138852 & 0.002351935 & Accept Ho & Not significant \\
\hline IV) & $\begin{array}{l}\text { Decision-making ability on } \\
\text { defining the problem }\end{array}$ & 2.262157163 & 0.527178879 & Accept Ho & Not significant \\
\hline V) & $\begin{array}{l}\text { Decision-making ability on } \\
\text { analyzing the problem }\end{array}$ & 2.109815578 & 0.803254683 & Accept Ho & Not significant \\
\hline VI) & $\begin{array}{l}\text { Decision-making ability on } \\
\text { making the decisions }\end{array}$ & 2.10092204 & 0.5736418 & Accept Ho & Not significant \\
\hline VII) & $\begin{array}{l}\text { Decision-making ability on } \\
\quad \text { executions and } \\
\text { implementations of decisions }\end{array}$ & 2.17881283 & 0.014462754 & Accept Ho & Not significant \\
\hline
\end{tabular}

T-Test: 0.05 level of significance.

Table 5. Relationship between MCDMA.

\begin{tabular}{ccccc}
\hline Correlations & $\begin{array}{c}\text { IV) } \\
\text { Defining the } \\
\text { problem }\end{array}$ & $\begin{array}{c}\text { V) } \\
\text { Analyzing } \\
\text { the problem }\end{array}$ & $\begin{array}{c}\text { VI) } \\
\text { Making the } \\
\text { decisions }\end{array}$ & $\begin{array}{c}\text { VII) Executions \& } \\
\text { implementations of } \\
\text { decisions }\end{array}$ \\
\hline I) Management of & 0.574 & 0.278 & 0.132 & 0.597 \\
planning procedures & 0.804 & 0.729 & 0.619 & 0.651 \\
II) Organization, control, \& & 0.609 & $0.387^{*}$ & 0.194 & 0.487 \\
direction of structures & 0.840 & 0.768 & 0.671 & 0.738 \\
& 0.701 & $0.385^{*}$ & 0.043 & 0.559 \\
III) Management of staff & 0.853 & 0.824 & 0.654 & 0.739 \\
\hline
\end{tabular}

${ }^{\star}$ Correlation is significant at the 0.05 level (2-tailed).

decision-making in order for them to arrive at a competent decision. Yet, Gorry \& Scott Morton (1971) stated that decision making is the core of management and aims at selecting the best alternative to achieve an objective.

\subsection{The Relation of Age and Length in the Service to the MCDMA}

\subsubsection{Relation of Age to the MCDMA of COPs}

For the COPs, Table 6 shows that the Computed Values is greater than Critical Values of areas II, III, V, and VII only. The Ho is rejected. This implies that both groups of respondents agree that Age affects the MCDMA of COPs only on the aforesaid areas. In the same view, an interview by the researcher with both groups of respondents revealed that the entire respondents believed that COPs must be mature so that they could successfully manage their personnel and 
Table 6. Relation of age to the MCDMA of COPs.

\begin{tabular}{|c|c|c|c|c|c|}
\hline \multicolumn{2}{|c|}{ I) Management of planning procedures } & \multirow{2}{*}{$\begin{array}{l}\text { Value } \\
-0.311\end{array}$} & \multirow{3}{*}{$\begin{array}{c}\text { Asymp. Std. Error }{ }^{\mathrm{a}} \\
0.108\end{array}$} & \multirow{3}{*}{$\begin{array}{c}\text { Approx. } \mathrm{T}^{\mathrm{b}} \\
-1.762\end{array}$} & \multirow{2}{*}{$\begin{array}{c}\text { Approx. Sig. } \\
0.089^{c}\end{array}$} \\
\hline Ordinal by ordinal & $\begin{array}{l}\text { Spearman } \\
\text { correlation }\end{array}$ & & & & \\
\hline \multirow[t]{2}{*}{$\mathrm{N}$ of valid cases } & $\mathrm{COPs}$ & 31 & & & Accept Ho \\
\hline & & 0.003 & 0.058 & 0.058 & $0.954^{\mathrm{c}}$ \\
\hline \multicolumn{2}{|c|}{ Police personnel } & 310 & & & Reject Ho \\
\hline \multicolumn{2}{|c|}{$\begin{array}{l}\text { II). Organization, control, \& direction } \\
\text { of structures }\end{array}$} & Value & Asymp. Std. Error ${ }^{a}$ & Approx. $\mathrm{T}^{\mathrm{b}}$ & Approx. Sig. \\
\hline Ordinal by ordinal & $\begin{array}{l}\text { Spearman } \\
\text { correlation }\end{array}$ & -0.082 & 0.16 & -.442 & $0.662^{\mathrm{c}}$ \\
\hline \multirow[t]{2}{*}{$\mathrm{N}$ of valid cases } & COPs & 31 & & & Reject Ho \\
\hline & & -0.033 & 0.058 & -.572 & $0.568^{c}$ \\
\hline \multicolumn{2}{|c|}{ Police personnel } & 310 & & & Reject Ho \\
\hline \multicolumn{2}{|c|}{ III) Management of staff } & Value & Asymp. Std. Error ${ }^{\mathrm{a}}$ & Approx. $\mathrm{T}^{\mathrm{b}}$ & Approx. Sig. \\
\hline Ordinal by ordinal & $\begin{array}{l}\text { Spearman } \\
\text { correlation }\end{array}$ & -0.006 & 0.22 & -.032 & $0.974^{\mathrm{c}}$ \\
\hline \multirow[t]{2}{*}{$\mathrm{N}$ of valid cases } & COPs & 31 & & & Reject Ho \\
\hline & & -0.038 & 0.056 & -.664 & $0.507^{\mathrm{c}}$ \\
\hline \multicolumn{2}{|c|}{ Police personnel } & 310 & & & Reject Ho \\
\hline \multicolumn{2}{|c|}{ IV) Defining problem } & Value & Asymp. Std. Error ${ }^{\mathrm{a}}$ & Approx. $\mathrm{T}^{\mathrm{b}}$ & Approx. Sig. \\
\hline Ordinal by ordinal & $\begin{array}{l}\text { Spearman } \\
\text { correlation }\end{array}$ & 0.248 & 0.18 & 1.379 & $0.178^{c}$ \\
\hline \multirow[t]{2}{*}{$\mathrm{N}$ of valid cases } & COPs & 31 & & & Accept Ho \\
\hline & & -0.048 & 0.057 & -.846 & $0.398^{\mathrm{c}}$ \\
\hline \multicolumn{2}{|c|}{ Police personnel } & 310 & & & Reject Ho \\
\hline \multicolumn{2}{|c|}{ V) Analyzing the problem } & Value & Asymp. Std. Error ${ }^{\mathrm{a}}$ & Approx. $\mathrm{T}^{\mathrm{b}}$ & Approx. Sig. \\
\hline Ordinal by ordinal & $\begin{array}{l}\text { Spearman } \\
\text { correlation }\end{array}$ & -0.105 & 0.179 & -0.571 & $0.572^{\mathrm{c}}$ \\
\hline \multirow[t]{2}{*}{$\mathrm{N}$ of valid cases } & COPs & 31 & & & Reject Ho \\
\hline & & -0.067 & 0.057 & -1.174 & $0.241^{\mathrm{c}}$ \\
\hline \multicolumn{2}{|c|}{ Police personnel } & 310 & & & Reject Ho \\
\hline \multicolumn{2}{|c|}{ VI) Making decisions } & Value & Asymp. Std. Error ${ }^{\mathrm{a}}$ & Approx. $\mathrm{T}^{\mathrm{b}}$ & Approx. Sig. \\
\hline Ordinal by ordinal & $\begin{array}{l}\text { Spearman } \\
\text { correlation }\end{array}$ & -0.390 & 0.118 & -2.282 & $0.030^{c}$ \\
\hline \multirow[t]{2}{*}{$\mathrm{N}$ of valid cases } & COPs & 31 & & & Accept Ho \\
\hline & & -0.037 & 0.058 & -0.653 & $0.514^{\mathrm{c}}$ \\
\hline \multicolumn{2}{|c|}{ Police personnel } & 310 & & & Reject Ho \\
\hline \multicolumn{2}{|c|}{$\begin{array}{l}\text { VII) Executions \& implementation of } \\
\text { decisions }\end{array}$} & Value & Asymp. Std. Error ${ }^{\mathrm{a}}$ & Approx. $\mathrm{T}^{\mathrm{b}}$ & Approx. Sig. \\
\hline Ordinal by ordinal & $\begin{array}{l}\text { Spearman } \\
\text { correlation }\end{array}$ & -0.016 & 0.184 & -0.087 & $0.931^{\mathrm{c}}$ \\
\hline \multirow{2}{*}{$\mathrm{N}$ of valid cases } & $\mathrm{COPs}$ & 31 & & & Reject Ho \\
\hline & & -0.007 & 0.058 & -0.128 & $0.898^{\mathrm{c}}$ \\
\hline \multicolumn{2}{|c|}{ Police personnel } & 310 & & & Reject Ho \\
\hline
\end{tabular}


could have a better decision-making ability. Wiersema \& Bantel (1992) indicated that younger managers tend to be more risk-oriented. On the contrary, Milana \& Maldaon (2015) concluded in their study that age of manager doesn't have a significant influence on organizational performance.... Lee, Yen, \& Chen (2008) stated that the impact of aging could diminish a manager's capacity to cope with the job of managing an organization. Also, Taylor (1975) found in his study that older managers are less facile information processors and decision makers. For the Police Personnel, Computed Values of all the areas are higher than their Critical Values. The Ho is rejected. Thus, Police Personnel perceived that there is a significant relation of Age on all the areas MCDMA.

\subsubsection{The Relation of Length in the Service to the MCDMA}

For the COPs, Table 7 shows that, except area VI, the rest of the areas have greater Computed Values than that of their Critical Values. The Ho is rejected. This implies that both groups of respondents agree that Length in the Service affects the MCDMA of COPs. For the Police Personnel, except area II, the rest of the areas have a higher Computed Value than that of their respective Critical Values. The Ho hypothesis is rejected. Thus, tenure of COPs could demonstrate better MCDMA. Both respondents agreed that COPs must have a longer length of service in order to successfully manage their personnel and could have a better decision-making ability. Similarly, Milana \& Maldaon (2015) also resolved in their study that tenure of manager has a significant and positive influence on organizational performance; when an organization has a long-tenured manager, he can influence an organizational performance.

Liu \& Ravichandran (2007) mentioned that as managers' tenure increases, they tend to become more committed to implementing their own pattern of how the organization should be run. Umukoro (2009) found out that long tenure of manager provides a better understanding of organizational procedures and policies, and unwillingness to change past ways of working. However, Wiersema \& Bantel (1992) said that long tenure probably reluctance to change structures existing and increases understanding of organizational procedures and policies. Also, Scott (2010) indicated that long tenure may lead to risk avoidance and aversion. Long tenured managers become committed to their model, and ignore calls for change.

\section{Conclusion}

As the study argued, the leadership of a Chief of Police in Nueva Ecija could be measured in terms of managerial competence and decision-making ability. This must go together to effect change in the police organization. However, as the study showed, there is a seeming disparity between the two leadership domains. Thus, the following conclusions:

1) The dichotomy between managerial competence and decision-making ability must be revisited. The COPs in the Province of Nueva Ecija are very much competent in terms of managerial aspect but have to improve their 
Table 7. Relation of length in the service to the MCDMA.

\begin{tabular}{|c|c|c|c|c|c|}
\hline \multicolumn{2}{|c|}{ I) Management of planning procedures } & \multirow{2}{*}{$\begin{array}{l}\text { Value } \\
-0.171\end{array}$} & \multirow{2}{*}{$\begin{array}{c}\text { Asymp. Std. Error }{ }^{\mathrm{a}} \\
0.15\end{array}$} & \multirow{2}{*}{$\begin{array}{c}\text { Approx. } \mathrm{T}^{\mathrm{b}} \\
-0.935\end{array}$} & \multirow{2}{*}{$\begin{array}{c}\text { Approx. Sig. } \\
0.357^{\mathrm{c}}\end{array}$} \\
\hline Ordinal by ordinal & $\begin{array}{l}\text { Spearman } \\
\text { correlation }\end{array}$ & & & & \\
\hline \multirow[t]{2}{*}{$\mathrm{N}$ of valid cases } & COPs & 31 & & & Reject Ho \\
\hline & & -0.055 & 0.059 & -0.975 & $0.330 \mathrm{c}$ \\
\hline \multicolumn{2}{|c|}{ Police personnel } & 310 & & & Reject Ho \\
\hline \multicolumn{2}{|c|}{$\begin{array}{c}\text { II) Organization, control, \& direction } \\
\text { of structures }\end{array}$} & Value & Asymp. Std. Error ${ }^{a}$ & Approx. $\mathrm{T}^{\mathrm{b}}$ & Approx. Sig. \\
\hline Ordinal by ordinal & $\begin{array}{l}\text { Spearman } \\
\text { correlation }\end{array}$ & -0.171 & 0.15 & -0.935 & $0.357^{\mathrm{c}}$ \\
\hline \multirow[t]{2}{*}{$\mathrm{N}$ of valid cases } & COPs & 31 & & & Reject Ho \\
\hline & & -0.096 & 0.058 & -1.7 & $0.090^{c}$ \\
\hline \multicolumn{2}{|c|}{ Police personnel } & 310 & & & Accept Ho \\
\hline \multicolumn{2}{|c|}{ III) Management of staff } & Value & Asymp. Std. Error ${ }^{\mathrm{a}}$ & Approx. $\mathrm{T}^{\mathrm{b}}$ & Approx. Sig. \\
\hline Ordinal by ordinal & $\begin{array}{l}\text { Spearman } \\
\text { correlation }\end{array}$ & 0.036 & 0.188 & 0.193 & $0.848^{\mathrm{c}}$ \\
\hline \multirow[t]{2}{*}{$\mathrm{N}$ of valid cases } & COPs & 31 & & & Reject Ho \\
\hline & & -0.077 & 0.058 & -1.355 & $0.177^{\mathrm{c}}$ \\
\hline \multicolumn{2}{|c|}{ Police personnel } & 310 & & & Reject Ho \\
\hline \multicolumn{2}{|c|}{ IV) Defining the Problem } & Value & Asymp. Std. Error ${ }^{a}$ & Approx. $\mathrm{T}^{\mathrm{b}}$ & Approx. Sig. \\
\hline Ordinal by ordinal & $\begin{array}{l}\text { Spearman } \\
\text { correlation }\end{array}$ & -0.165 & 0.177 & -0.899 & $0.376^{c}$ \\
\hline \multirow[t]{2}{*}{$\mathrm{N}$ of valid cases } & COPs & 31 & & & Reject Ho \\
\hline & & -0.08 & 0.058 & -1.401 & $0.162^{c}$ \\
\hline \multicolumn{2}{|c|}{ Police personnel } & 310 & & & Reject Ho \\
\hline \multicolumn{2}{|c|}{ V) Analyzing problem } & Value & Asymp. Std. Error ${ }^{\mathrm{a}}$ & Approx. $\mathrm{T}^{\mathrm{b}}$ & Approx. Sig. \\
\hline Ordinal by ordinal & $\begin{array}{l}\text { Spearman } \\
\text { correlation }\end{array}$ & -0.216 & 0.19 & -1.19 & $.244^{\mathrm{c}}$ \\
\hline \multirow[t]{2}{*}{$\mathrm{N}$ of valid cases } & COPs & 31 & & & Reject Ho \\
\hline & & -0.093 & 0.057 & -1.637 & $0.103^{c}$ \\
\hline \multicolumn{2}{|c|}{ Police personnel } & 310 & & & Reject Ho \\
\hline \multicolumn{2}{|c|}{ VI) Making decisions } & Value & Asymp. Std. Error ${ }^{\mathrm{a}}$ & Approx. $\mathrm{T}^{\mathrm{b}}$ & Approx. Sig. \\
\hline Ordinal by ordinal & $\begin{array}{l}\text { Spearman } \\
\text { correlation }\end{array}$ & -0.307 & 0.172 & -1.734 & $0.093^{c}$ \\
\hline \multirow[t]{2}{*}{$\mathrm{N}$ of valid cases } & $\mathrm{COPs}$ & 31 & & & Accept Ho \\
\hline & & -0.071 & 0.056 & -1.257 & $0.210^{c}$ \\
\hline \multicolumn{2}{|c|}{ Police personnel } & 310 & & & Reject Ho \\
\hline \multicolumn{2}{|c|}{$\begin{array}{l}\text { VII) Executions \& implementations of } \\
\text { decisions }\end{array}$} & Value & Asymp. Std. Error ${ }^{a}$ & Approx. $\mathrm{T}^{\mathrm{b}}$ & Approx. Sig. \\
\hline Ordinal by ordinal & $\begin{array}{l}\text { Spearman } \\
\text { correlation }\end{array}$ & -0.004 & 0.178 & -0.022 & $0.983^{c}$ \\
\hline \multirow[t]{2}{*}{$\mathrm{N}$ of valid cases } & COPs & 31 & & & Reject Ho \\
\hline & & -0.003 & 0.058 & -0.061 & $0.951^{\mathrm{c}}$ \\
\hline \multicolumn{2}{|c|}{ Police personnel } & 310 & & & Reject Ho \\
\hline
\end{tabular}


decision-making ability. It is, of course, necessary for a COP to know the do's and don'ts of his position especially the management aspect of it, but remains weak in terms of decision-making ability. Management competence provides organizational advantage to police stations. However, this managerial competence must be coupled with the decisiveness to issue orders emanating from study and analysis of the situations confronting the Police Station. The COPs cannot completely and meritoriously perform their function because they are only efficient in managerial aspect. Hence, COPs must be proficient both in managerial and decision-making; therefore, COPs' in-service trainings should both focus on the managerial and decision-making aspects.

2) The fact that the study showed that COPs are competent in managerial aspect does not mean proficiency in decision-making. However, as a leader, managerial ability is relatively associated in some decision-making areas, but mostly, they differ in various areas. Thus, it is recommended that regular and rigorous trainings on both domains be accorded to the COPs.

3) Finally, age and length in the service are significant factors in management and decision-making. Thus, it is suggested that those who would be promoted to the position of COP must have served the police for quite a long time as their experiences could harness their leadership skills and make them effective and efficient Chief of Police compared to those young police officers.

\section{References}

(1987). Philippine Constitution (Article XVI, Section 6).

(1998). Republic Act 8551 (Philippine National Police Reform and Reorganization Act of 1998) (Section 2, par. 2 and 3 February 25).

Bohm, R. M. \& Haley, K. N. (2005). Introduction to Criminal Justice (4th ed.). New York, NY: McGraw-Hill.

Bryman, A., Stephens, M., \& Campo, C. (1996). The Importance of Context: Qualitative Research and the Study of Leadership. The Leadership Quarterly, 7, 353-370. https://doi.org/10.1016/S1048-9843(96)90025-9

Calder, B. J. (1977). An Attribution Theory of Leadership. New Directions in Organizational Behavior, 179, 204.

Drucker, P. F. (1974). Management: Tasks, Responsibilities, Practices. New York, NY: Harper \& Row.

Fabinyi, M. (2007). Illegal Fishing and Masculinity in the Philippines a Look at the Calamianes Islands in Palawan. Philippine Studies, 55, 509-529.

Fayol, H. (1947). General and Industrial Management. London: Pitman.

Fyfe, J. J., Greene, J. R., Walsh, W. F., Wilson, O. W., \& McLaren, R. C. (1997). Police Administration (5th ed.). New York: McGraw-Hill, Google Scholar.

Gabriel, A. G. (2017). Indigenous Women and the Law: The Consciousness of Marginalized Women in the Philippines. Asian Journal of Women's Studies, 23, 250-263. https://doi.org/10.1080/12259276.2017.1317705

Gaylord, M. S., \& Galliher, J. F. (1991). Riding the Underground Dragon: Crime Control and Public Order on Hong Kong's Mass Transit Railway. The British Journal of Criminology, 31, 15-26. https://doi.org/10.1093/oxfordjournals.bjc.a048082 
Google Map. Province of Nueva EcijaMap. https://www.google.com.ph/search?q=map+of+nueva+ecija\&dcr=0\&source=lnms\&tb $\underline{\mathrm{m}=\mathrm{isch} \& \mathrm{sa}=\mathrm{X} \& \mathrm{ved}=0 \mathrm{ahUKEwi} \text {-jqrvh4jXAhVHmpQKHQCzBacQ_AUICigB\&biw=13 }}$ 66\&bih=662\#imgrc=HR3c_BU6K-z-NM

Gorry, G., \& Scott Morton, M. S. (1971). A Framework for Management Information System. Sloan Management Review, 13, 55-70.

Guibong, P. D. (1994). The Capacity of Police Officers Assigned to the Intelligence and Investigation Section of Cabanatuan City Police Station. Master's Thesis, Araullo University, Cabanatuan City.

Ireland, R. D. \& Miller, C. C. (2004). Decision Making and Firm Success. Academy of Management Executive, 18, 8-12. https://doi.org/10.5465/AME.2004.15268665

Kelling, G. L. (1999). Broken Windows and Police Discretion. NCJ178259. 6 p.

Koontz, H., \& O’Donnell, C. (1972). Principles of Management. New York: McHraw-Hill.

Kumar, R. (2014). Research Methodology: A Step-by-Step Guide for Beginners (4th ed.) SAGE. CA: Thousand Oaks.

Lee, J., Yen, P., \& Chen, Y. (2008). Longer Tenure, Greater Seniority, or Both? Evidence from Open-End Equity Mutual Fund Managers in Taiwan. Asian Academy of Management Journal of Accounting and Finance, 4, 1-20.

http://web.usm.my/journal/aamjaf/vol\%204-2-2008/4-2-1.pdf

Liu, Y., \& Ravichandran, T. (2007). Information Technology Capital, Managerial Human Capital, and Firm Performance: An Empirical Investigation. European Conference on Information Systems, 994-1006.

http://aisel.aisnet.org/cgi/viewcontent.cgi? article=1087\&context=ecis2007

Milana, E., \& Maldaon, I. (2015). Managerial Characteristics and Its Impact on Organizational Performance: Evidence from Syria. Business: Theory and Practice, 16, 215-216, 219.

Ortmeier, P. J., \& Davis, J. J. (2012). Police Administration: A Leadership Approach (Kindle Edition, 21 p). New York, NY: McGraw-Hill Global Education Holdings. https://www.amazon.com/Police-Administration-Leadership-Ortmeier-Professor/dp/0 $\underline{073380008}$

Pitz, G. F., \& McKillip, J. (1984). Decision Analysis for Program Evaluators (p. 14). SAGE Publications, Inc.

Rodriguez, R. A., \& Echancis, E. S. (2001). Fundamentals of Management, Text and Philippine Cases (4th ed.).

Scott, E. (2010). Tenure, Functional Track and Strategic Leadership. International Journal of Educational Management, 24, 448-458. https://doi.org/10.1108/09513541011056009

Swanson, C. R., Territo, L., \& Taylor, R. W. (2008). Police Administration, Structures, Processes, and Behavior (7th ed.). Pearson Education.

Taylor, R. N. (1975). Age and Experience as Determinants of Managerial Information Processing and Decision Making Performance. Academy of Management Journal 18, $74-81$.

http://amj.aom.org/content/18/1/74 https://doi.org/10.2307/255626

Timpac, T. M. (2012). A Handbook on Police Organization and Administration with Police Planning (1st ed., p. 9). RMC Publishing Haus.

Umukoro, F. (2009). The Effects Managerial Characteristics and Organization Growth on Strategic Change. Revista Empresarial Inter Metro/Inter Metro Business Journal, 5, 1-21. http://ceajournal.metro.inter.edu/spring09/umukoro0501.pdf 
Van der Ploeg, J., Van Weerd, M., Masipiqueña, A. B., \& Persoon, G. A. (2011). Illegal Logging in the Northern Sierra Madre Natural Park, the Philippines. Conservation and Society, 9, 202-215. https://doi.org/10.4103/0972-4923.86991

Weitzer, R. (2002). Incidents of Police Misconduct and Public Opinion. Journal of Criminal Justice, 30, 397-408. https://doi.org/10.1016/S0047-2352(02)00150-2

Wiersema, M. F., \&Bantel, K. A. (1992). Top Management Team Demography and Corporate Strategic Change. Academy of Management Journal, 35, 91-121. https://doi.org/10.2307/256474

Worall, J. L., Gaines, L. K., Southerland, M. D., \& Angell, J. E. (2003). Police Administration (2nd ed.). New York, NY: McGraw-Hill Publishing Company, Inc. 


\section{Appendix}

\section{Questionnaire checklist}

I) Respondent's Profile: Kindly check $(\sqrt{ })$ the blank lines below according to your profile.

Name (Optional):

Name of Police Station:

Age:

$21-30$

$31-40$

$41-56:$

Years in the Service:

0 - 10 Years:

11 - 20 Years:

21 Years above:

II) Please encircle $(\mathrm{O})$ the rate that corresponds to your answer.

The following scale will be used:

4) Always/Very Much Competent (A/VMC) - It is carried out to a full extent.

3) Very Often/Very Competent (VO/VC) - It is carried out to a good extent.

2) Often/Competent $(\mathrm{O} / \mathrm{C})$ - It is carried out to an average or fairly good extent.

1) Rarely/Slightly Competent (R/SC) - It is carried out to a very poor extent.

\begin{tabular}{|c|c|c|c|c|c|}
\hline \multicolumn{6}{|c|}{ I) Managerial Competence in Management of Planning Procedures } \\
\hline 1 & I/he design/s \& conduct/s needs assessment preparatory to planning. & 4 & 3 & 2 & 1 \\
\hline 2 & I/he anticipate/s the needs of the police office $\&$ develop/s administrative procedures. & 4 & 3 & 2 & 1 \\
\hline 3 & I/he formulate/s a definite, well-organized plan of activities, \& is systematic. & 4 & 3 & 2 & 1 \\
\hline 4 & $\begin{array}{l}\mathrm{I} / \text { he encourage/s my/his subordinates to work cooperatively in planning \& in implementing PNP } \\
\text { objectives \& policies. }\end{array}$ & 4 & 3 & 2 & 1 \\
\hline 5 & I/he utilize/s the resources, manpower \& energy productivity. & 4 & 3 & 2 & 1 \\
\hline 6 & I/he select/s alternatives; make/s assumptions in planning the PNP activities. & 4 & 3 & 2 & 1 \\
\hline 7 & I/he study/ies the implications of plans; use/s foresights. & 4 & 3 & 2 & 1 \\
\hline 8 & $\begin{array}{l}\text { I/he make/s certain that committee of group meetings is preceded by well-planned agenda, } \\
\text { analyses, \& proposals. }\end{array}$ & 4 & 3 & 2 & 1 \\
\hline 9 & I/he see/s to it that plans are understood by those involved. & 4 & 3 & 2 & 1 \\
\hline 10 & $\mathrm{I} / \mathrm{he}$ see/s to it that my/his personnel have the needed equipment \& materials. & 4 & 3 & 2 & 1 \\
\hline \multicolumn{6}{|c|}{ II) Managerial Competence in Organization, Control, and Direction of Structures } \\
\hline 1 & I/he display/s innovativeness in implementing PNP policies \& regulations. & 4 & 3 & 2 & 1 \\
\hline 2 & I/he ask/s for feedback data $\&$ revise/s procedures in concurrence with the data. & 4 & 3 & 2 & 1 \\
\hline 3 & I/he provide/s workshops, seminars, \& other in-service trainings for my/his personnel. & 4 & 3 & 2 & 1 \\
\hline 4 & I/he organize/s office work to win the respect of my/his subordinates, clients or citizens. & 4 & 3 & 2 & 1 \\
\hline 5 & I/he have/has a regular but flexible schedule for accomplishing routine works. & 4 & 3 & 2 & 1 \\
\hline 6 & I/he display/s punctuality in fulfilling $\mathrm{my} / \mathrm{his}$ duties. & 4 & 3 & 2 & 1 \\
\hline 7 & $\begin{array}{l}\text { I/he delegate/s authority \& clarify/ies responsibilities of those supervisee enabling them to meet } \\
\text { fully what is expected of them. }\end{array}$ & 4 & 3 & 2 & 1 \\
\hline
\end{tabular}




\section{Continued}

8 I/he enforce/s organizational rules, regulations, and policies.

9

I/he have/has the ability to handle office problems.

$\begin{array}{llll}4 & 3 & 2 & 1\end{array}$

$10 \mathrm{I} / \mathrm{he}$ keep/s confidentiality \& security of records.

$\begin{array}{llll}4 & 3 & 2 & 1\end{array}$

III) Managerial Competence in Management of Staff

1 I/he administer/s personnel policies \& procedures of organizational system carefully \& consistently.

2 I/he carry/ies out roles as "manager" in cooperation with my/his personnel.

3 I/he provide/s leadership in extra-curricular activities.

4 I/he "coach/es" my/his subordinates and promotes their professional growth \& development.

5 I/he assign/s my/his subordinates work which they are suited to.

I/he avoid/s reporting of negative criticisms on my/his subordinates to the higher officials without first having discussed the matter with the people concerned.

7 I/he avoid/s using my/his influence to force my/his members to subscribe to things

I/he display/s a genuine interest in the personal, social, \& the family interest of my/his ubordinates.

I/he promote/s harmony in performing police functions \& holding social interchange among my/his subordinates.

10 I/he provide/s educational \& social growth of my/his subordinates such as scholarships, trainings, social activities etc.

\section{IV) Decision-Making Ability in Defining the Problem}

1 I/he explain/s actions made to my/his subordinates.

I/he provide/s opportunities to my/his subordinates to participate in defining the problems of the police station.

$3 \mathrm{I} /$ he put/s the suggestions of my/his members into operation.

4 I/he sit by myself/himself \& see/s all the angles of the problem in the police station.

$5 \mathrm{I} /$ he confer/s with the members on all matters that concern them.

6 I/he have/has a system of feedback that helps analyze each PNP member under my/his control on their/our strengths or weaknesses.

7 I/he involve/s my/his subordinates in making the PNP objectives.

$8 \quad \mathrm{I} / \mathrm{he}$ utilize/s the power of fellow policemen in making decisions.

9 I/he give/s that feeling of "let's get things done" in every work related meetings or conferences.

$10 \mathrm{I} /$ he solicit/s staff or subordinate's help/s in defining the problems of the police station.

\begin{tabular}{llll}
4 & 3 & 2 & 1 \\
4 & 3 & 2 & 1 \\
4 & 3 & 2 & 1 \\
4 & 3 & 2 & 1 \\
4 & 3 & 2 & 1 \\
4 & 3 & 2 & 1 \\
4 & 3 & 2 & 1 \\
4 & 3 & 2 & 1 \\
4 & 3 & 2 & 1 \\
4 & 3 & 2 & 1 \\
\hline
\end{tabular}

$\begin{array}{llll}4 & 3 & 2 & 1 \\ 4 & 3 & 2 & 1 \\ 4 & 3 & 2 & 1 \\ 4 & 3 & 2 & 1 \\ 4 & 3 & 2 & 1 \\ 4 & 3 & 2 & 1 \\ 4 & 3 & 2 & 1 \\ 4 & 3 & 2 & 1 \\ 4 & 3 & 2 & 1 \\ 4 & 3 & 2 & 1\end{array}$

\section{V) Decision-Making Ability in Analyzing the Problem}

$1 \mathrm{I} /$ he assign/s my/his personnel on their exact jobs.

4

I/he realize/s the potential power of my/his staff.

$3 \mathrm{I} /$ he encourage/s that there is an evidence of love interest on $\mathrm{my} / \mathrm{his}$ personnel \& to me/him as $\mathrm{COP} / \mathrm{manager} /$ administrator in implementing PNP objectives.

$4 \mathrm{I} /$ he get/s my/his staff's approval of decisions made before going ahead.

$5 \mathrm{I} / \mathrm{he}$ am/is easily influenced by my/his staff in analyzing the problems of the police station. public safety.

7 I/he am/is jealous of the ideas of my/his staff when they make good proposals.

8 I/he make/s all duty detail scheduling decisions.
4

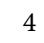

4

4

4

4

4

4
3

3

2

1

$3 \quad 2$

$\begin{array}{lll}3 & 2 & 1\end{array}$

$\begin{array}{lll}3 & 2 & 1\end{array}$

$\begin{array}{lll}3 & 2 & 1\end{array}$

$3 \quad 2$

$\begin{array}{lll}3 & 2\end{array}$




\section{Continued}

9 I/he solve/s reported crimes if crime prevention measures failed.

10

$\mathrm{I} / \mathrm{h}$ attend/s serious problems related to $\mathrm{my} / \mathrm{his}$ work \&do/does not always delegate grave dilemma to $\mathrm{my} / \mathrm{his}$ subordinates.

VI) Decision-Making Ability in Making the Decisions

1 I/he encourage/s participation in making decisions.

2 I/he give/s explicit information \& make/s the staff know what is expected of them.

3 I/he demand/s strict observance of the rules \& regulations from my/his subordinates.

$4 \mathrm{I} / \mathrm{he}$ consult/s my/his staff before finalizing a decision.

5 I/he make/s a decision/s affecting my/his members without consulting them.

6 I/he leave/s the choice of the decision entirely to the group.

7 I/he adopt/s unilateral decision making.

$8 \mathrm{I} / \mathrm{he}$ refuse/s to acknowledge autocratic decisions.

$9 \mathrm{I} / \mathrm{he}$ am/is slow in making decisions that need immediate action.

$10 \mathrm{I} /$ he establish/es a well-defined pattern of getting the work done.

$\begin{array}{llll}4 & 3 & 2 & 1 \\ 4 & 3 & 2 & 1\end{array}$

\section{(1)}

